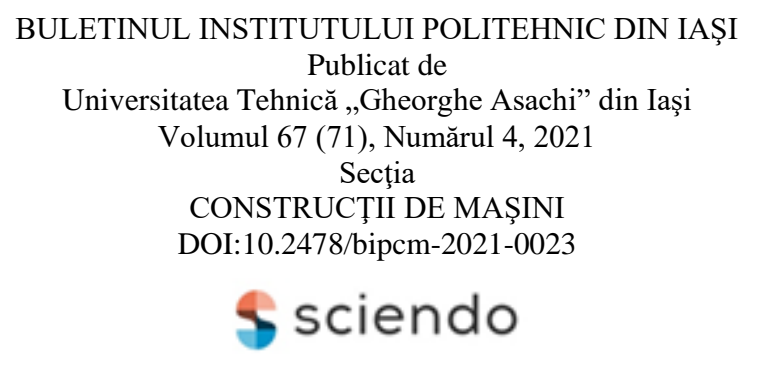

\title{
AN EMPIRICAL ESTIMATION OF CUTTING FORCE FOR FACE MILLING USING A STATIONARY DYNAMOMETER
}

\author{
BY
}

\section{CRISTIAN CROITORU*}

"Gheorghe Asachi" Technical University of Iaşi, Faculty of Machines Manufacturing and Industrial Management

Received: November 30, 2021

Accepted for publication: December 14, 2021

Abstract. Being known the lack of information about constants that appear in the Kienzle relationship, this work proposes a solution to reduce the effort required to customize their values.

Applied to face milling, the proposed procedure makes it possible to identify the coefficients in the case of turning, using experiments under certain conditions of similarity, which are then used to calculate the principal cutting force in the case of milling.

The proposed procedure uses a stationary dynamometer both to measure the cutting force in the case of turning and to calculate the tangential force in the case of face milling.

The experiments carried out have tried to simulate a real processing case for industry, the worpiece material being used as supplied by the supplier.

Keywords: specific cutting force; single cutting milling face; stationary dynamometer; cutting force coefficients; dry machining.

*Corresponding author; e-mail: ccroitoru@tuiasi.ro (C) 2021 Cristian Croitoru

This is an open access article licensed under the Creative Commons Attribution-NonCommercialNoDerivatives 4.0 International License (CC BY-NC-ND 4.0). 


\section{Introduction}

It is difficult to predict cutting forces in discontinuous processes due to the large number of interacting processing parameters. There are analytical and empirical approaches to predicting these forces.

Analytical methods are based on phenomena that appear on the tool's contact surface when it comes into contact with chips that move during cutting.

For the calculation of the cutting forces these methods use a given experimental series for certain parameters.

Empirical methods are an alternative to calculating the cutting forces employed by industry. The empirical approach is based on the use of constants and curve fitting, generally linear interpolations. These methods use coefficients and constants which are determined by experiments.

Empirical methods are based on the notion of cutting resistance or specific cutting force $k_{c}$ introduced by Kienzle and Victor.

The specific cutting force $k_{c}$ is based on the relationship between the theoretical thickness of undetached $h_{D}$ chip and two constants, $k_{c 1.1}$ and $m_{c}$ constants, according to relationship:

$$
k_{c}=\frac{k_{c 1.1}}{h_{D}^{1-m_{c}}}
$$

where $k_{c 1.1}$ could be called the unit-specific cutting force and $m_{c}$ is the exponent of the specific cutting force.

It should be noted that although heavily dependent on the mechanical characteristics of the processed material, $k_{c}$ cannot be designated as a physical characteristic because it depends on the combination of phenomena that occur on both the mating and clearance faces of the tool (Stahl and de Vos, 2014). For this reason, $k_{c}$ cannot be used to characterize the processing of a particular material (Toenshoff and Denkena, 2013).

Usually, the values of both the specific cutting force and the two constants are specified in the documentation provided by industrial firms. Based solely on practical experiment, the values of these constants may not be translated under different conditions.

It is of particular importance in the establishment of the $k_{c 1.1}$ and $m_{c}$ constants the preparation of cutting edge, especially the presence of different negative lands on the rake face and edge rounding (Fig. 1, Rech, 2005). 


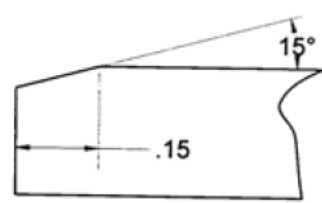

Chamfered edge

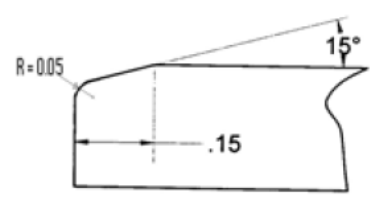

\section{Chamfered +} honed edge

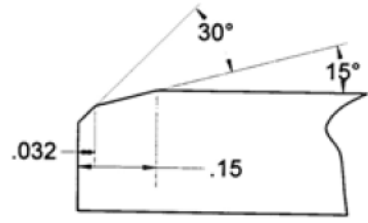

Doublechamfered edge

Fig. 1 - Some typical edge preparation on c-BN insert.

For the empirical method of predicting forces to be useful, the two constants in the Kienzle relationship should be specified for each geometry of the cutting tool (existing or future) and for each material to be processed. be specified:

As regards the materials currently used in industry, the following can

- characteristics of workpieces often differ from their standard specifications (higher or lower values for hardness and/or breaking strength);

- the materials processed by cutting are permanently diversified, which makes it unlikely that the two constants will be determined beforehand.

All these observations lead to the conclusion that the accuracy of the empirical prediction of the chipping forces is significantly affected by the lack of such data.

The present work proposes a solution that "shortens" the laborious work to customize the values of the constants in the Kienzle relationship for each possible edge geometry and for each material processed by cutting.

The basic idea of the method is to identify the coefficients $k_{c 1.1}$ and $m_{c}$ in the case of turning and to use them for calculating the tangential cutting force $F_{c}$ in the case of milling, using identical tools for both turning and face milling.

Experimental research has been carried out under normal working conditions for the industry, the workpiece material being used as supplied by the supplier, without any preliminary heat treatment being carried out.

\section{Specific Cutting Force}

The Kienzle force model for main component describes the relationship between the effective cutting area $A_{c}$ (Fig. 2) and the tangential cutting force component as following:

$$
k_{C}=\frac{F_{C}}{A_{C}}
$$



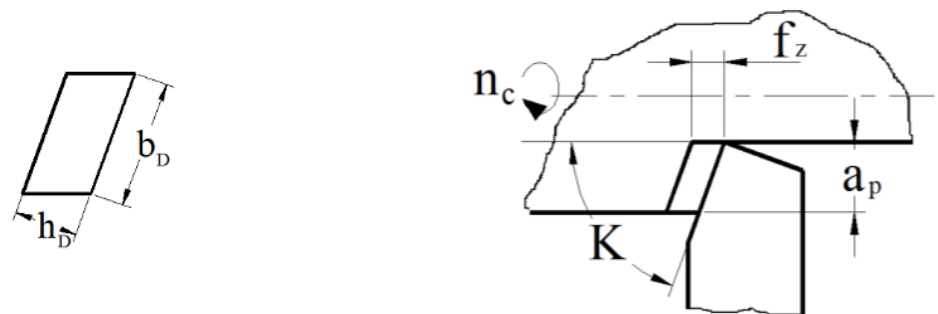

Fig. 2 - Effective cutting area $A_{C}$. Fig. 3 - Dimensions of the chip in turning. relationship:

In turning operation, the effective cutting area is given by

$$
A_{C}=h_{D} \cdot b_{D}=a_{p} \cdot f_{z}
$$

where:

$h_{D}$ is the thickness of the $\operatorname{chip}\left(h_{D}=f_{z} \cdot \sin K\right)$,

$b_{D}$ is the width of the $\operatorname{chip}\left(b_{D}=a_{p} / \sin K\right)$,

$K$ is the main cutting angle,

$f_{z}$ is the feed per rotation (Fig. 3),

$a_{p}$ is the cutting depth.

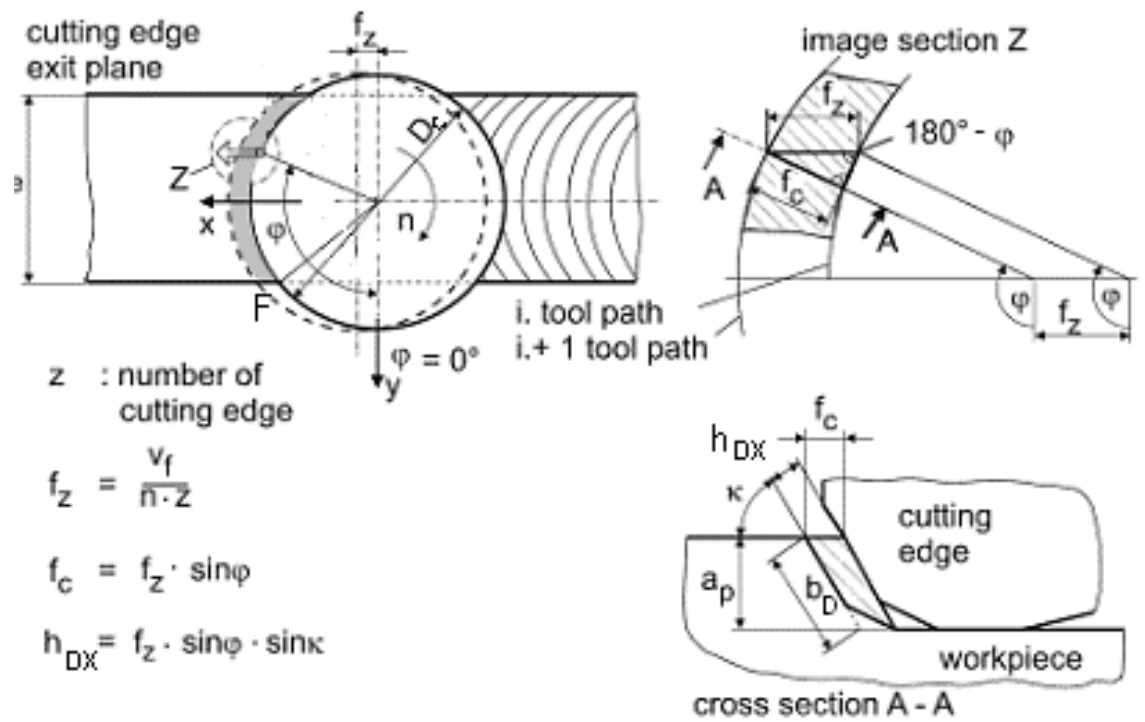

Fig. 4 - Dimensions of the chip in face milling. 
During face milling process, the instantaneous thickness of the chip depends on the tooth rotation angle $\varphi$ (see Fig. 4):

$$
h_{D x}=f_{z} \cdot \sin \varphi \cdot \sin K
$$

where $\varphi$ is the angular position of the tooth on the arc of contact of the tool with the workpiece.

In this case the instantaneous value of cutting force $F_{c}$ changes for each angle value of $\varphi$ according to the relationship below:

$$
F_{C}=k_{c} \cdot h_{D x} \cdot b_{D}=k_{c} \cdot f_{z} \cdot a_{p}
$$

or combining with relationship (1):

$$
F_{C}=k_{c 1.1} \cdot b_{D} \cdot h_{D x}^{1-m_{c}}
$$

\section{Describing Method}

The aim of the method is to determine by experimental means the cutting force in the case of turning, and the subsequent use of the data for the calculation of the cutting force in face milling case.

The proposed method involves going through the next steps:

- determining the constants of Kienzle Eq. (1) in turning case;

- calculation of the cutting force $F_{c}$ (main cutting force) in the case of face milling by means of the relationship (6);

- experimental checking of the force $F_{c}$ calculated using the relationship $(6)$

In order to increase the experimental rate and to increase the precision of the experiment, the two experiments should be carried out under identical conditions, i.e.:

- the materials of the two workpieces must be identical;

- the geometric parameters of the two cutting tools must be identical (especially the microgeometry of the cutting edge);

- use of a single experimental data acquisition unit for both turning and milling operations.

\section{Experimental Procedure and Evaluation of Cutting Forces}

\subsection{Process Parameters for Turning}

The two workpieces were made from the same bar of cold rolled steel of Ck22 (DIN Germany) or OLC 20 (STAS 880), 1020 (AISI), 1044 (DIN). 
The chemical composition of the specimen we used is the following: $\mathrm{C}=0.219 \%, \mathrm{Mn}=0.698 \%, \mathrm{Si}=0.155 \%, \mathrm{Cr}=0.148 \%, \mathrm{Cu}=0.130 \%, \mathrm{P}=0.03 \%$, and its medium hardness is $190 \mathrm{HB}_{2.5 / 62.5}$.

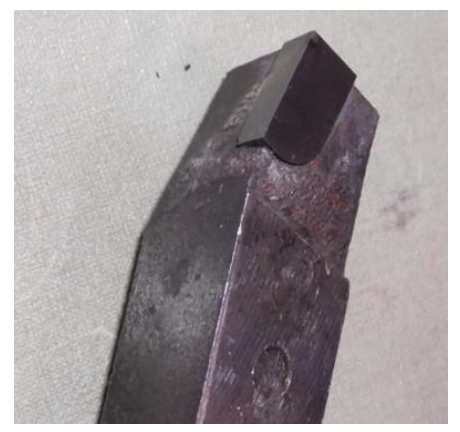

Fig. 5 - Cutting tool for turning.

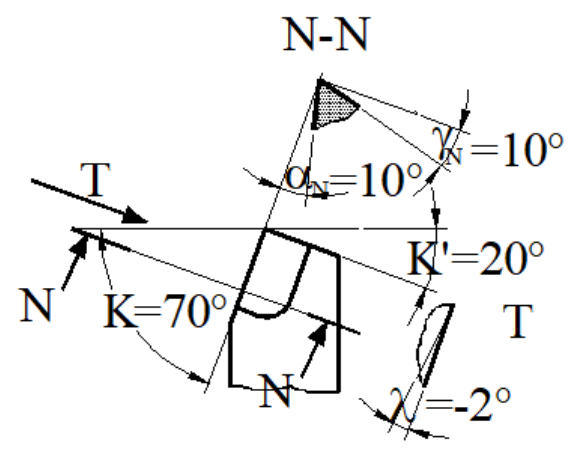

Fig. 6-Geometry of turning tool.

The turning experiments were performed on a conventional lathe SNA $560 \times 1500$ in dry conditions.

The cutting tool selected during both machining experiments (turning and milling) was a P20 ISO carbide insert (Fig. 5) having the geometry given in Fig. 6:

- major cutting angle $\mathrm{K}=70^{\circ}$, minor cutting angle $\mathrm{K}^{\prime}=20^{\circ}$;

- major clearance angle $\alpha_{N}=10^{\circ}$;

- major rake angle $\gamma_{N}=10^{\circ}$, (cutting angle $\delta_{N}=80^{\circ}$ ), inclination angle $\lambda=0^{\circ}$

- experimental checking of the force $F_{c}$ calculated calculated using the Eq. (6);

- nose radius $\mathrm{R}<0.05 \mathrm{~mm}$.

Table 1 shows the cutting conditions for turning experiments.

Table 1

Cutting Conditions for Turning

\begin{tabular}{||l|l||}
\hline Workpiece geometry & cylinder \\
\hline Outer diameter $[\mathrm{mm}]$ & 60 \\
\hline Length $[\mathrm{mm}]$ & 100 \\
\hline Depth of cut, $a_{p}[\mathrm{~mm}]$ & 1 \\
\hline Feed per revolution $[\mathrm{mm} / \mathrm{rev}]$ & $0.16,0.20,0.25$ \\
\hline Spindle rotation $(\mathrm{rot} / \mathrm{min})$ & 400 \\
\hline Cutting speed $[\mathrm{m} / \mathrm{min}]$ & 75.4 \\
\hline Cutting type & dry cutting \\
\hline
\end{tabular}




\subsection{Process Parameters for Face Milling}

The milling experiments were performed on a conventional milling machine type FUS 32.

The cutting tool was a fly cutter which allows the use of the turning tool used in the turning experiment (Fig. 7).
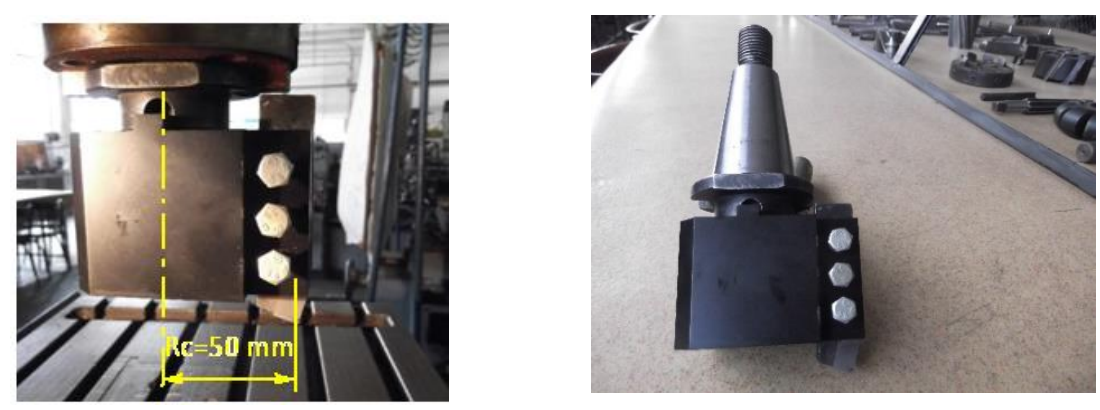

Fig. 7 - Fly cutter utilized for face milling.

Table 2 shows the cutting conditions for milling experiments.

Table 2

Cutting Conditions for Milling

\begin{tabular}{||l|l||}
\hline Workpiece geometry & parallelepiped \\
\hline Dimensions of workpiece $[\mathrm{mm}]$ & $100 \times 50 \times 25$ \\
\hline Axial engagement $a_{p}[\mathrm{~mm}]$ & 1 \\
\hline Feed per revolution $[\mathrm{mm} / \mathrm{rev}]$ & 0.162 \\
\hline Spindle rotation $(\mathrm{rot} / \mathrm{min})$ & 400 \\
\hline Cutting speed $[\mathrm{m} / \mathrm{min}]$ & 78.5 \\
\hline Feed rate $[\mathrm{mm} / \mathrm{min}]$ & 40.5 \\
\hline Diameter of cutter $[\mathrm{mm}]$ & 100 \\
\hline Cutting type & dry cutting \\
\hline
\end{tabular}

\subsection{Experimental Equipment}

A measuring system comprised a stationary four component dynamometer (Kistler 9272), Kistler 5070 charge amplifier and a DynoWare type $2825 \mathrm{~A}$ was utilized to measure the cutting forces in both sets of experiments (turning and milling).

For each experiment, were recorded the evolution of components $F_{z}\left(F_{c}\right)$, $F_{x}\left(F_{f}\right)$ and were calculated their average values (Fig. 8 and Fig. 9). 


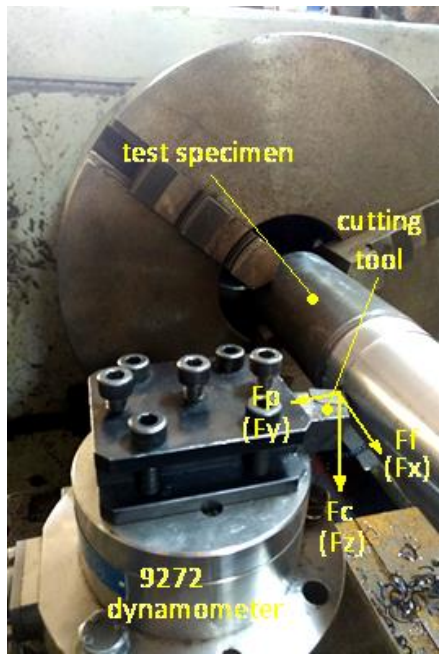

Fig. 8 - Experimental set-up for turning.
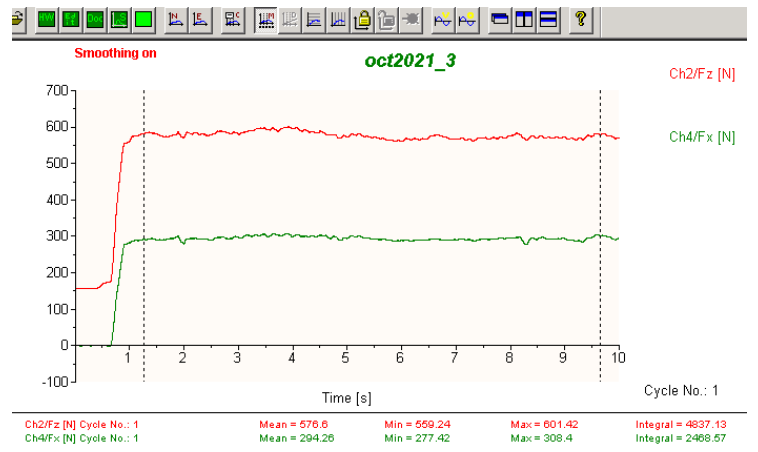

Fig. 9 - Registration of the cutting force components.

Since the stationary dynamometers do not allow direct measurement of the chipping force in the case of milling (Grigorievna et al., 2015), a previously validated methodology (Croitoru and Bocăneț, 2020) has been adopted, consisting of the following:

- the dynamometer measurement of the components $F_{x}$ and $F_{y}$ of the fixed Mxy system (Fig. 10);

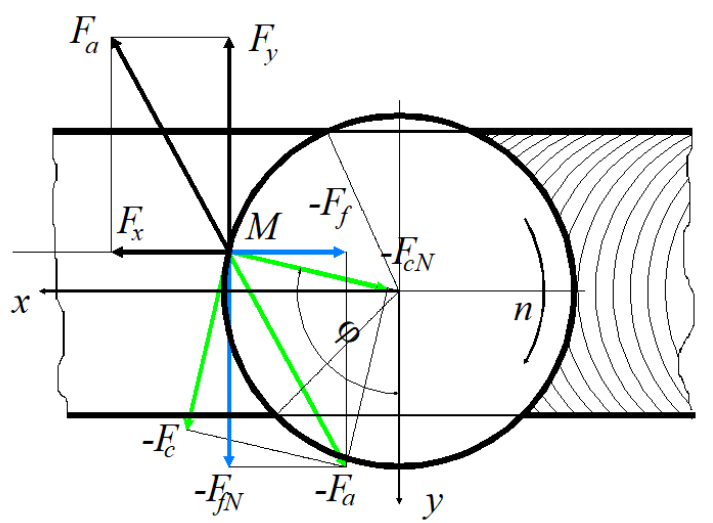

Fig. 10 - Decomposing of cutting force in face milling.

- calculation of the active force $F_{a}$;

- determination by calculation of the cutting force $F_{c}$. 
The measurement of components $F_{x}$ and $F_{y}$ was carried out according to the set-up shown in Fig. 11, the position of the tool in relation to the workpiece being that shown in Fig. 12.

The calculation of the active component $F_{a}$ and the cutting component $F_{c}$ (tangential component) has been carried out in accordance with the previously submitted methodology (Croitoru and Bocăneț, 2020).

The two components $F_{x}$ and $F_{y}$ have been recorded (collected) at an acquisition rate of $1000 \mathrm{~Hz}$. In this way it was possible to record forces for every $1.5^{\circ}$ degrees of the cutter's movement.

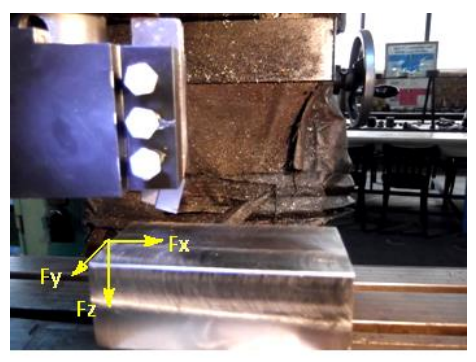

Fig. 11 - Experimental set-up for milling.

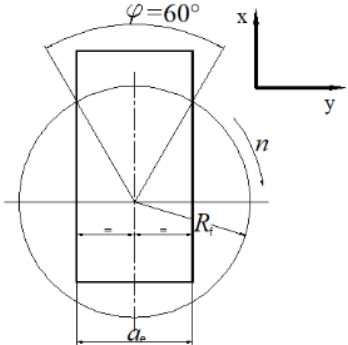

Fig. 12 - Position of the cutter against workpiece.

\section{Results and Discussion}

The experiments carried out in the case of turning have been carried out in random order, according to data presented in Table 3.

Table 3

The Average of Measurement Component $F_{c}\left(F_{z}\right)$

\begin{tabular}{|c|c|c|c||}
\hline \hline$f_{z}[\mathrm{~mm} / \mathrm{rot}]$ & $b_{D}[\mathrm{~mm}]$ & $a_{p}[\mathrm{~mm}]$ & $F_{c}\left(F_{z}\right)$ \\
\hline 0.160 & 1.06 & 1 & 451 \\
\hline 0.200 & 1.06 & 1 & 524 \\
\hline 0.235 & 1.06 & 1 & 576 \\
\hline
\end{tabular}

Applying the logarithm function to Eq. (6), the linear equation is considered:

$$
\log \frac{F_{c}}{b_{D}}=\log k_{c 1.1}+\left(1-m_{c}\right) \cdot \log h_{D}
$$

Following the methodology set out (Croitoru et al., 2015), the data presented in Table 4 were calculated. 


\section{Table 4}

$\log \frac{F_{C}}{b_{D}}$ and $\log h_{D}, b_{D}=1.06 \mathrm{~mm}$ and $b_{D}=1 \mathrm{~mm}$

\begin{tabular}{|c|c|c|c||}
\hline$f[\mathrm{~mm}]$ & 0.16 & 0.20 & 0.235 \\
\hline$h_{D}[\mathrm{~mm}]$ & 0.15 & 0.187 & 0.18 \\
\hline $\log h_{D}$ & -0.8239 & -0.7281 & -0.6289 \\
\hline$F_{c}[\mathrm{~N}]$ & 451.13 & 523.96 & 576.6 \\
\hline$\frac{F_{c}}{b_{D}^{*}}$ & 451.13 & 523.96 & 576.6 \\
\hline$\frac{F_{c}}{1}[\mathrm{~N}]$ & 425.59 & 494.3 & 543.96 \\
\hline $\log \frac{F_{c}}{1}$ & 2.629 & 2.694 & 2.735 \\
\hline
\end{tabular}

$b_{D}{ }^{*}=1.06 \mathrm{~mm}$

Using the values in Table 4, the interpolation line of Eq. (7) is plotted as seen in Fig. 13 representing the interpolation line that particularizes the Eq. (7) as (8).

$$
\log \frac{F_{c}}{1}=3.08061+0.5428 \cdot \log h_{D}
$$

From this relationship were deducted values of the two constants $k_{c 1.1}$ and $m_{c}$ :

- $k_{c 1.1}=1202 \mathrm{~N} / \mathrm{mm}^{2}$

- $m_{c}=0.4572$

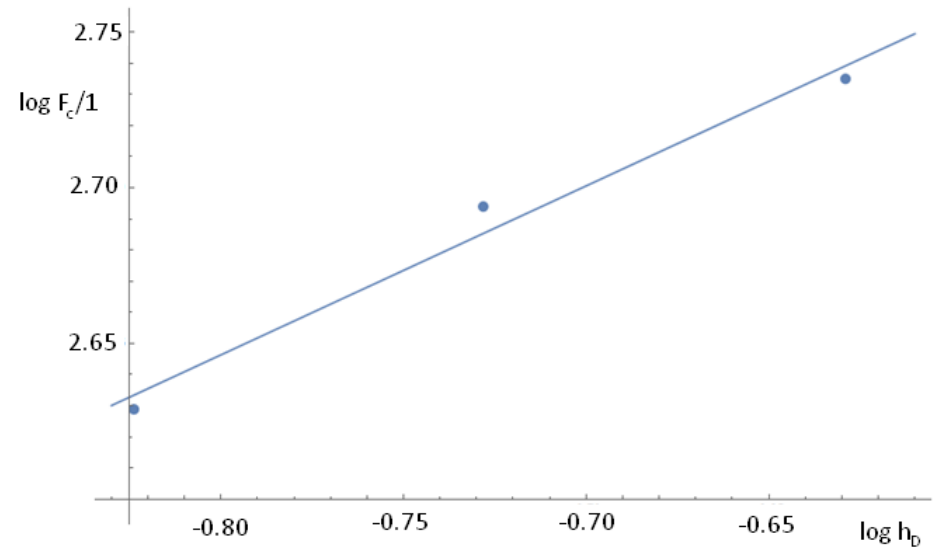

Fig. 13 - Plot of experimental data in $\log F_{c}$ and $\log h_{D}$ coordinates. 
Calculation of the active force $F_{a}$ has been deduced from the geometric relationship (Fig. 10):

$$
F_{a}=\sqrt{F_{x}^{2}+F_{y}^{2}}=\sqrt{F_{f}^{2}+F_{f N}^{2}}
$$

This equation was used to plot the graph of active force $F_{a}$ shown in Fig. 14.

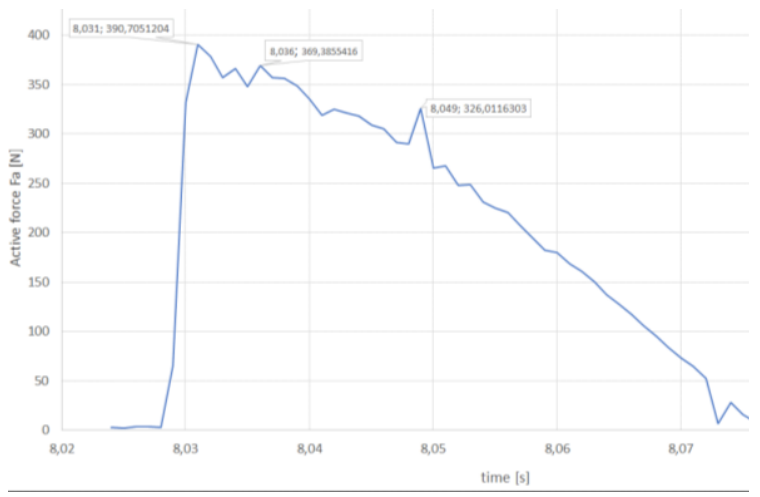

Fig. 14 - Calculated force component $F_{a}$.

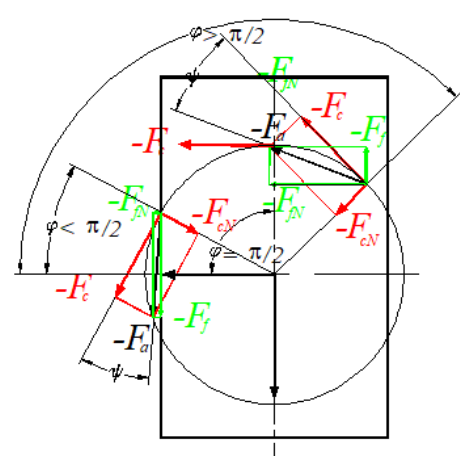

Fig. 15 - Dependence of $F_{c}$ of $\varphi$ angle.

For the calculation of the cutting force $F_{c}$, were used relationships depending on position of the tooth on the contact arc (see Eq. (1), (2), and (3) from Croitoru and Bocăneț, 2020):

$$
F_{c}=F_{a} \cdot \cos \psi=F_{a} \cdot \cos \left(\varphi-\operatorname{arcos} \frac{F_{f}}{F_{a}}\right)
$$

if $\varphi<\pi / 2$;

$$
F_{c}=F_{a} \cdot \cos \psi=F_{a} \cdot \cos \left(\varphi+\operatorname{arcos} \frac{F_{f}}{F_{a}}-\pi\right)
$$

if $\varphi>\pi / 2$;

$$
F_{c}=F_{f N}=F_{y}
$$

if $\varphi=\pi / 2$, 
where $\varphi$ is the angle of the position of the tooth on the contact arc and $\psi$ is the angle between $F_{c}$ and $F_{a}$ (Fig. 15).

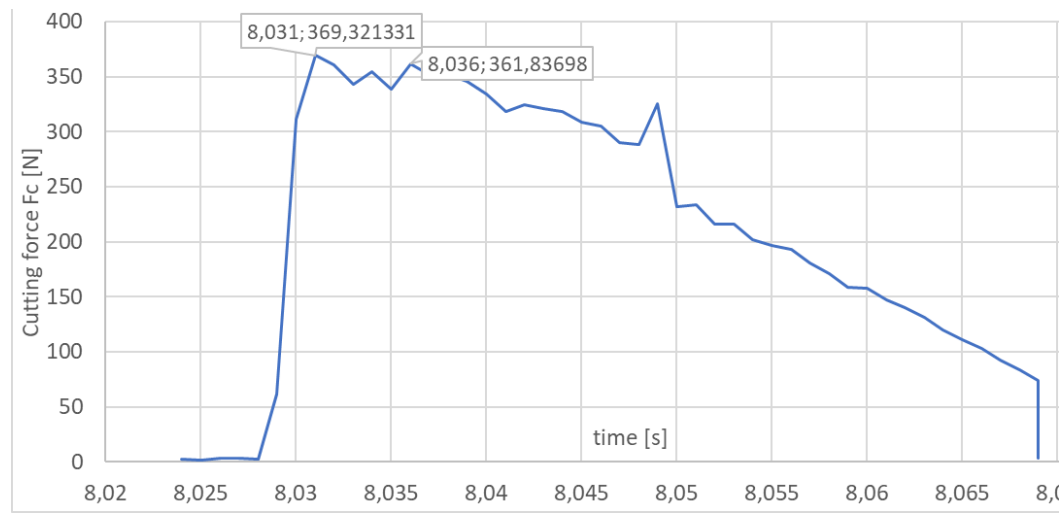

Fig. 16 - Calculated force component $F_{c}$.

Using these values, the graph of calculated cutting force $F_{c}$ was plotted as seen in Fig. 16.

The following remarks can be made with regard to the magnitude of the values of forces measured or calculated in this work:

- the average measured value of the cutting force $F_{c}\left(F_{z}\right)$ when turning is $451 \mathrm{~N}$ (Table 3);

- the maximum calculated value of the cutting force $F_{c}$ is $369 \mathrm{~N}$ for face milling (Fig. 16);

- the difference between the measured value (in the case of turning) and the calculated value (in the case of milling) is $81 \mathrm{~N}$, representing $18 \%$ of the measured value;

The result can be considered satisfactory given view of the following:

- both workpieces were made of the same cold rolled steel bar without heat treatment (steel without annealing);

- the lack of annealing treatment can be the cause of large differences in the hardness of the workpiece $\left(\mathrm{HB}_{\min }=178, \mathrm{HB}_{\max }=209\right)$.

With the help of the relationship 6, the theoretical evolution of cutting force $F_{c}$ for the contact arc of the tool with the workpiece in Fig. 14 was plotted. The following observations can be made by comparing the calculated force development $F_{c}$ (Fig. 16) with the theoretical evolution (Fig. 17):

- the peak value of the force $F_{c}$ calculated from the relationship 6 is very close to that of the mean value measured in the case of turning (difference of approximately $3 \%$ ) which theoretically confirms the approach taken;

- the experimentally determined curve $F_{c}$ (Fig. 16) shows an eccentricity in relation to the axis of symmetry of the workpiece, the explanation 
of which may be the positioning error of the tool and/or the non-parallelism between the axis of symmetry of the workpiece and the direction of the feed movement.

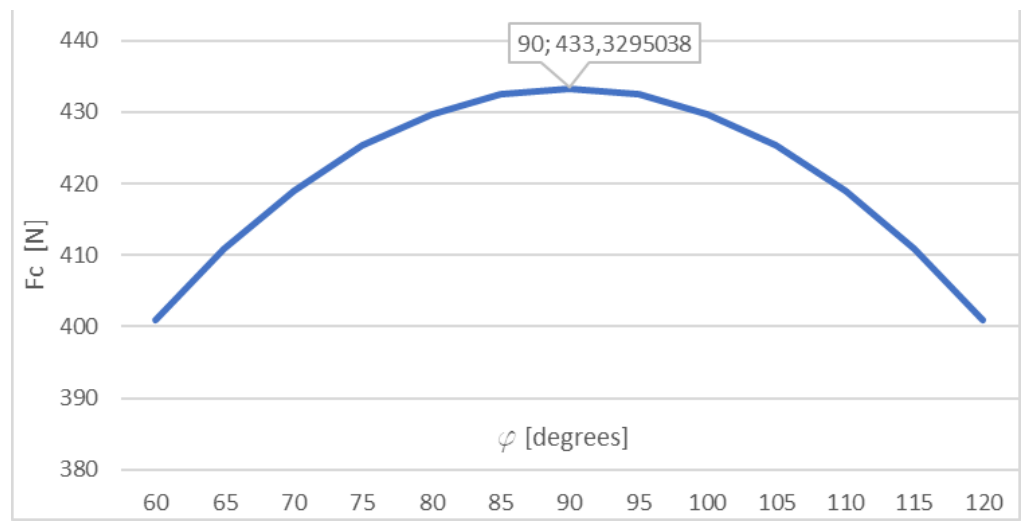

Fig. 17 - Calculated theoretical force component $F_{c}$.

\section{Conclusions}

The present work proposes a shorter alternative to laborious work for customizing constants from the Kienzle relationship, for if the mechanical characteristics of the semi-manufactured material or the geometric parameters of the tool are not found in literature.

The work is experimental and uses a method of identifying the $k_{c l . l}$ and $m_{c}$ coefficients in the Kienzle relationship when turning and using them for the calculation of the tangential component $F_{c}$ in the case of trimming, observing the condition of identity between the geometric parameters of the two tools.

The experimental tests were carried out using a stationary dynamometer, which measured cutting force $F_{c}$ in the case of turning and calculated $F_{c}$ in the case of face milling (since this dynamometer cannot directly measure the tangential force).

For both phases of the experimental tests, the same cutting tool was used, both workpieces coming from the same piece of steel.

An attempt was made to simulate a real processing case, in the sense that the workpiece material was used as supplied by the supplier, without any preliminary heat treatment being carried out.

As regards the size of the $F_{c}$ cutting forces measured (when turning) and calculated (when trimming), the result can be said to be satisfactory, with the two values differing by less than $20 \%$. The difference can be attributed to the differences in hardness of the workpieces (the workpieces were made of the same cold rolled steel bar). 
With respect to the maximum force $F_{c}$ calculated for face milling, it is very close to that measured during turning, the difference being less than $3 \%$.

Further study directions can be mentioned:

- diversification of research through the adoption of other types of metallic and non-metallic materials for workpieces;

- use of tools with different micro-geometries (tools reinforced with mechanically clamped cutting inserts, having different lands on the rake face, different edge rounding, overcoating with different materials, etc.).

\section{REFERENCES}

Croitoru C., Bocăneț A-M., Chelariu R., Chicet D., Evaluation of Machinability of AlCu11 Cast Alloy at Conventional Cutting Speeds, Bul. Inst. Polit. Iaşi, s. Construcţii de Maşini, LXI (LXV), 2, 131-142 (2015).

Croitoru C., Bocăneț A.-M., Experimental Investigation of the Influence of Cutting Edge Reinforcement on Specific Cutting Force, Bul. Inst. Polit. Iaşi, s. Construcţii de Maşini, LXII (LXVI), 2, (2016).

Croitoru C., Bocăneţ A.-M., An Experimental Method to Evaluate the Active Force in Face Milling, Bul. Inst. Polit. Iaşi, s. Construcţii de Maşini, 65 (69), 3, 9-15 (2019).

Croitoru C., Bocăneţ A.-M., An Experimental Method to Evaluate the Cutting Force in Face Milling, Bul. Inst. Polit. Iaşi, s. Construcţii de Maşini, 66 (70), 3, 9-16 (2020).

Grigorieva S. N., Volosova M. A., Gurin V. D., Seleznyov A.Ye., Investigation of Force Parameters Acting on a Single Cutting Insert Made of Ceramics in Face Milling of Hardened Steel, Mechanics \& Industry, 16, $702-707$ (2015).

Rech J., Cutting Edge Preparation and Surface Issues, HSS Forum's International Conference «Smart solutions for metal cutting », Aachen, 2-3 February 2005.

Stahl J-E., de Vos P., Metal Cutting Theories in Practice, SECO TOOLS AB, LundFagersta, Sweden 2014, 02980331, ST20146464 GB.

Toenshoff H.K., Denkena B., Basics of Cutting and Abrasive Processes, Springer-Verlag Berlin Heidelberg 2013.

\section{ESTIMARE EMPIRICĂ A FORȚEI DE AȘCHIERE \\ LA FREZAREA FRONTALĂ UTILIZÂND UN DINAMOMETRU STAȚIONAR}

(Rezumat)

Numărul mare de parametri de prelucrare face ca predicția forțelor de așchiere să fie deosebit de dificilă în cazul prelucrărilor prin frezare.

În prezent pentru predicția acestor forțe există abordări analitice și empirice, fiecare din acestea având nevoie de o serie de parametri sau constante ce trebuie 
determinate experimental și a căror extrapolare în afara domeniului în care au fost realizate este inacceptabilă.

Lucrarea de față propune o soluție care "scurtcircuitează" munca laborioasă pentru particularizarea constantelor din relaţia lui Kienzle (cea mai utilizată pentru metodele empirice de predicție a forțelor) pentru fiecare geometrie a tăișului și pentru fiecare material așchiat.

Ideea de bază a metodei constă din identificarea coeficienților din relația Kienzle în cazul strunjirii și utilizarea lor pentru calculul forței de aşchiere în cazul frezării frontale.

Cercetările experimentale s-au efectuat în condiții de lucru obișnuite pentru industrie, materialul semifabricatului fiind utilizat aşa cum a fost livrat de furnizor, fără efectuarea vreunui tratament termic preliminar, iar determinarea forțelor s-a realizat cu ajutorul unui dinamometru multi-component. 